\title{
Preface to the Siberian lakes special issue
}

\author{
Ramesh D. Gulati · Wolf M. Mooij • \\ Andrey G. Degermendzhy
}

Received: 3 August 2010/Accepted: 4 August 2010/Published online: 17 August 2010

(C) The Author(s) 2010. This article is published with open access at Springerlink.com

This Special Issue of Aquatic Ecology is an update on the ongoing limnological studies on the ecosystems of two saline, meromictic lakes, Lake Shira and Lake Shunet, both located in southern Siberia (Khakasia, Russia). Lake Shira can be termed as a 'natural laboratory' for investigations into the lower limits of biodiversity, in view of the complete absence of fish and cladoceran zooplankton in this water body (see below). Both Lake Shira and the neighbouring Lake Shunt have been the focus of limnological research by the Institute of Biophysics (IBP), Krasnoyarsk, Siberian Branch of the Russian Academy of Science (SB-RAS), since the late 1990s. Below, we provide a brief historical resume of this research programme and then focus on the main findings documented in this special issue.

This first, international cooperative study on the Siberian lakes was carried out from 1999 to 2002 by the IBP and The Netherlands Institute of Ecology of the Royal Netherlands Academy of Science (NIOOKNAW), Nieuwersluis. The universities of Madrid,

Handling editor: Piet Spaak.

R. D. Gulati $(\bowtie) \cdot$ W. M. Mooij

Netherlands Institute of Ecology (NIOO-KNAW),

Nieuwersluis, The Netherlands

e-mail: r.gulati@nioo.knaw.nl

\section{A. G. Degermendzhy}

Institute of Biophysics (SB-RAS), Krasnoyarsk, Siberia,

Russia
Spain (Prof. Antonio Quesada), Zurich, Switzerland (Prof. Friedrich Jüttner) and the Institute of Computational Modelling, Krasnoyarsk (SB-RAS), were the other main participants. The study on Lake Shira during the first three-years (1999-2001) by this international research team was funded by the European Union (EU) INTAS Grant 97-O519 to the IBP. Two of the undersigned-Andrey G. Degermendzhy, head of the IBP, Krasnoyarsk, and Ramesh D. Gulati, of NIOO-KNAW, Nieuwersluiswere among most active collaborators in this early project. The complete study titled The structure and functioning of Lake Shira ecosystem: an example of Siberian brackish water lakes was published in Aquatic Ecology as a Special Issue (36/2) containing 18 papers (Gulati and Degermendzhy 2002). In addition to summarising studies on the bacterial production, protozoan bacterivory, phytoplankton, the growth of dominant zooplankton and the microbial food web of Lake Shira, this study described the geography and geology, as well as provided data on salient features of water chemistry of Khakasian lakes.

The above-mentioned published study formed the basis of a concerted, follow-up research project between The Netherlands and Russia from 2005 to 2008. This new project was funded jointly by the Netherlands Organization for Scientific Research and the Russian Foundation for Basic Research (NWORFBR grant 047.017.012), with one of the undersigned (Wolf M. Mooij) as project coordinator. In 
addition to research grants to individual Russian scientists and the funding of the laboratory facilities, including equipment, the subsidy enabled the travel to and from Siberia by three Dutch scientists (Ramesh D. Gulati, Wolf M. Mooij and Jan H. Janse) to participate in the project workshops held in 2006 and 2008. Also, many of the Russian project collaborators utilized the funds to travel to and stay at the Netherlands Institute of Ecology, Nieuwersluis, for work visits of several weeks.

The ten contributions in this present Special Issue of Aquatic Ecology not only update the research studies on Lake Shira thus far but also provide some comparisons between Lake Shira and Lake Shunet, which is the much smaller and shallower of these two meromictic lakes. Both lakes are frozen during the long winter period that stretches from late October/early November to late May. The present study is related mainly to the rather high stability of stratification of the lakes and the associated physical-chemical and biological phenomena, which are reinforced mainly by the high salinity of incoming water at the lake bottom.

In both lakes, Shira and Shunet, stable stratification results in an upper, mixed layer called that is oxic, and a lower, perennial layer monimolimnion, which is anoxic. Between these two major strata, a relatively thin oxic-anoxic interphase layer, chemocline, develops. Whereas within the mixolimnion in Lake Shira, a thermocline (sharp temperature gradient) is invariably formed in summer during calm and warm days, such a thermal gradient is absent in Lake Shunet. This is because the lake is very shallow, the mixolimnion is rather thin and well mixed. The chemocline depth determines the development and vertical positioning of the bacterial community in the lake. In contrast, in Lake Shunet, the salinity gradient being more well defined the depth of the chemocline appears to depend on bacterial activity. Whereas in Lake Shira, both purple sulphur bacteria and sulphate-reducing bacteria are encountered in the chemocline, in Lake Shunet, green sulphur bacteria are also present. Moreover, in Lake Shunet, both phytoflagellates and ciliates form dense communities in the chemocline. Interestingly, of both the lakes, the presence of the primarily a littoral-benthic species, Gammarus lacustris, in the pelagic region (its secondary habitat), raises questions. Both lakes contain a mixolimnetic population of Arctodiaptomus salinus: the feeding spectrum of this calanoid, based on fatty acid (FA) markers, reveals that the composition of seston in the two lakes differs only moderately. Whereas the FA markers in Lake Shira reveal more green algae and Cyanobacteria markers, in Lake Shunet, the diatom FA markers were higher.

In summary, the uniqueness of these saline Siberian lakes, in addition to their high salinity, lies in their surroundings and arid climate and the prevailing severe winter weather conditions. The meromixis and annual stable stratification, and the associated phenomena are reinforced greatly by the high salinity originating from the lake bottom. The food chain in both lakes is highly truncated and simple, with no fish, only a few zooplankton species, and a total absence of herbivorous cladocerans. There is a prevalence of the heterotrophic flagellates, including species in the deeper anoxic layers, and heterotrophic productivity contributes significantly to overall productivity of the lake. The littoral zoobenthos is represented only by Gammarus sp., which also occurs in the lake pelagial. These particular features were captured in a new Lake Shira ecosystem model that is fully documented in this special issue.

Stimulated by the inspiring contacts between Dutch and Russian ecosystem modellers and with Russian mathematicians, an even bigger spin-off of the project emerged, the value of which transcends the research on lakes Shira and Shunet. As documented in the last paper in this special issue, a large group of ecosystem modellers and limnologists, from 25 institutions in 15 countries all around the world, joined forces to try to avoid in the future two wasteful trends of the past in the field of lake ecosystem modelling: 'reinventing the wheel' and 'having tunnel vision'. Under the title 'Challenges and opportunities of integrating lake ecosystem modelling approaches', this group of experts makes a plea for improving the awareness of existing models and concurrent approaches in lake ecosystem modelling. These approaches include static models, complex dynamic models, structurally dynamic models, minimal dynamic models and various individual-based approaches. The point of view agreed upon is that a single 'right' modelling format does not exist and should not be strived for. Instead, multiple modelling formats, applied concurrently to a given problem, can help develop an integrative view on the functioning of lake ecosystems around the world. Thus, not only were the empirical conclusions derived from the 
earlier study expanded, and models of the Siberian lakes improved, but the Dutch-Russian collaborative project also provided a basis for future exciting developments in the field of lake ecosystem modelling in general.

Each of the papers in this special issue was reviewed by two or three referees. Both the authors and we, the editors, express a deep gratitude to all the reviewers, many of them anonymous. We are also grateful to all the authors of papers included in this Special Issue: the authors adhered very well to the protocol drawn by us for the manuscript preparation, submission or resubmission of their revised manuscripts. This saved us as editors much work. We are grateful to Prof. Ellen van Donk for her support to the project at the Netherlands Institute of Ecology. We thank Dr. Egor Zadereev for acting as a liaison between the Siberian and Dutch research teams and his help to us at even odd hours in the preparation of this Special; Egor also acted as corresponding author of a synthesis paper, integrating all the empirical findings and the state-of-the-art information on the two Siberian lakes. We are highly thankful to
Dr. Donald L. DeAngelis (University of Miami, Coral Gables, Florida, USA) for his willingness to join and to contribute to the final project workshop, held at Krasnoyarsk in 2008, and for writing the Foreword to this special issue. We agree with Don's closing remarks during the workshop discussion that the Dutch-Russian collaborative research project that is documented in this special issue of Aquatic Ecology resulted in state-of-the-art limnological research on lakes Shira and Shunet and will lead to new collaborations between the partners involved.

Open Access This article is distributed under the terms of the Creative Commons Attribution Noncommercial License which permits any noncommercial use, distribution, and reproduction in any medium, provided the original author(s) and source are credited.

\section{Reference}

Gulati RD, Degermendzhy AG (2002) The structure and functioning of Lake Shira ecosystem: an example of Siberian brackish water lakes. Aquat Ecol 36(2):105-340 